\title{
OSCILLATION OF SECOND ORDER NONLINEAR DIFFERENTIAL EQUATION WITH SUB-LINEAR NEUTRAL TERM
}

\author{
Sivaraj TAMILVANAN, ETHIRAJU ThANDAPANi, JOZEF DŽURINA
}

Abstract. In this paper the authors established sufficient conditions for the oscillation of all solutions of a nonlinear differential equation

$$
\left(a(t)\left(x(t)+p(t) x^{\alpha}(\tau(t))\right)^{\prime}\right)^{\prime}+q(t) x^{\beta}(\sigma(t))=0, t \geqslant t_{0},
$$

where $\alpha$ and $\beta$ are ratio of odd positive integers. The results obtained here extend and improve some of the existing results. Examples are included to illustrate the importance of the results.

Mathematics subject classification (2010): 34C10, 34K11.

Keywords and phrases: neutral differential equation, sub-linear neutral term, oscillation.

\section{REFERENCES}

[1] R.P. Agarwal, M. Bohner And W.T. Li, Nonoscillation and Oscillation: Theory of Functional Differential Equation, Marcel Dekker, New York., 2004.

[2] R.P. Agarwal and S.R. GRACE, Oscillation theorems for certain neutral differential equations, Comput. Math. Appl., 38 (1999), 1-11.

[3] R.P. Agarwal, M.Bohner, T. Li And C. ZHAng, Oscillation of second order differential equations with a sublinear neutral term, Carpathian J. Math., 30 (2014), 1-6.

[4] B. BACULÍKOVÁ AND J. DŽURINA, Oscillation theorems for second order nonlinear neutral differential equations, Comput. Math. Appl., 61 (2011), 94-99.

[5] L.H. ERBe, Q. Kong And B.G. Zhang, Oscillation Theory For Functional Differential Equations, Marcel Dekker, New York., 1995.

[6] S.R. GRACE AND B.S. LALLI, Oscillation of solutions of nonlinear neutral second order delay differential equations, Rad. Mat., 3 (1987), 77-84.

[7] I. Gyori And G. Ladas, Oscillation Theory of Delay Differential Equations with Applications, Clarendan Press, Oxford., 1991.

[8] J.K. Hale, Theory of Functional Differential Equations, Springer, New York., 1987.

[9] M. HaSANBUlLi AND Y. V. RogovCHENKo, Oscillation criteria for second order nonlinear neutral differential equations, Appl. Math.Comput., 215 (2010), 4392-4399.

[10] G. S. Ladde, V. LaKshmikantham and B.G. Zhang, Oscillation Theory of Differential Equations with Deviating Arguments, Marcel Dekker, New York., 1987.

[11] T. LI, R.P. AGARWAL AND M. BOHNER, Some oscillation results for second order neutral differential equations, J. Indian Math. Soc., 79 (2012), 97-106.

[12] T. LI, Z.HAN, C.ZHANG AND H. LI, Oscillation criteria for second order superlinear neutral differential equations, Abstr. Appl. Anal., 2011 (2011), 1-17.

[13] T. Li, Z.HAN, C.ZHANG AND S. Sun, On the oscillation of second order Emden-Fowler neutral differential equations, J. Appl. Math. Comput., 37 (2011), 601-610.

[14] T. LI, YU.V. RogOVCHENKO AND C. ZHANG, Oscillation of second order neutral differential equations, Funke. Ekvac., 56 (2013), 111-120. 
[15] T. SAKAmoto AND S. TANAKA, Eventually positive solutions of first order nonlinear differential equations with a deviating arguments, Acta Math. Hungar., 127 (2010), 17-33.

[16] S.H. SAKER AND J.V. MANOJLOVIC, Oscillation criteria for second order superlinear neutral delay differential equations, Electran. J. Qual. Theory Differ. Equ., 10 (2004), 1-22.

[17] S. Sun, T. LI, Z.HAN AND C. ZHANG, On oscillation of second order nonlinear neutral functional differential equations, Bull. Malays. Math. Sci. Soc., 36 (2013), 541-554.

[18] E. Thandapani AND R. RAma, Comparison and oscillation theorems for second order nonlinear neutral differential equations, Serdica Math.J., 39 (2013), 1-16.

[19] R. XU AND F.W. MENG, Oscillation criteria for second order quasilinear neutral delay differential equations, Appl. Math. Comput., 192 (2007), 216-222. 